\section{高周波点灯専用形蛍光ランプ用器具(2) 一環形蛍光灯器具一}

The Trend of High Frequency Inverter Lighting Fixture (2) - with Circular Fluorescent Lamp-

\キーワード：高周波点灯専用蛍灯ランプ, 省エネ・省資源・高効率, 環形蛍光ランプ, 環形蛍光ランプ用器具

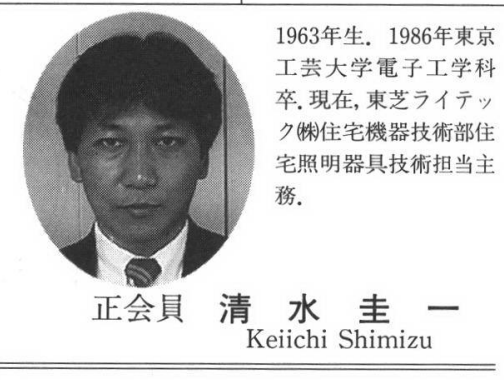

ることになる

\section{1.はじめに}

最近の住宅照明の現状を調査した結果で，72\%の世帯 で蛍光灯器具が多いとの調查結果1) (図 1 ) があるよう に日本の住宅用照明器具は他国に比べ蛍光灯器具が多い 分，既に省工ネは進んでいるとも言えるのではないだろ うか。

それは，他国に先駆けて環形の蛍光ランプが商品化さ れたことが大きく, 環形の蛍光ランプは日本の居住空間, 生活にマッチしたのか急速に普及したことが大きく影響 していると考える。そんな環形蛍光ランプではあるが, ランプ管径の細形化による消費電力の低減，三波長域発 光形蛍光体による明るさアップ, 演色性改善に続き, 最 近高周波点灯専用ランプとして更なる細形化, 明るさ アップ, 省エネがはかられ器具形状, 性能も変わってき た.ここでは住宅用照明器具を中心に, 新しい 2 タイプ の高周波点灯専用形環形蛍光ランプを使った照明器具に ついて概要, 特徵を説明する。

\section{2. 住宅用照明器具の流れ}

先にも述べたように, 裸電球の吊り下げ器具から始 まった住宅用の照明器具は, 環形蛍光ランプの出現によ ク大幅に明るさアップ, 省エネへと変わっていくことに なる. 天井の引掛シーリングローゼットの普及もあり, 簡単に取付できる吊り下げ器具は，やがて高周波点灯装 置 (インバー夕) の出現により明るさアップ, 省エネ, 軽量化と進んでいく．磁気コイル式安定器からインバー タへの移行という点灯装置の軽量化により照明器具も軽 くなり, 吊り下げ器具以外にも直付器具も引掛シーリン グローゼットにより取り付けできる器具が現れ，住宅用 の照明器具は居住空間をもっとスッキリ使いたいという 要望もあり, 環形ランプの吊り下げ器具から環形蛍光ラ ンプの直付器具へと大きく移行し, 更なる薄型化, 明る さアップ, 省エネを求めるようになる。そして, 細形の 高周波点灯専用形環形蛍光ランプを使った器具が生まれ

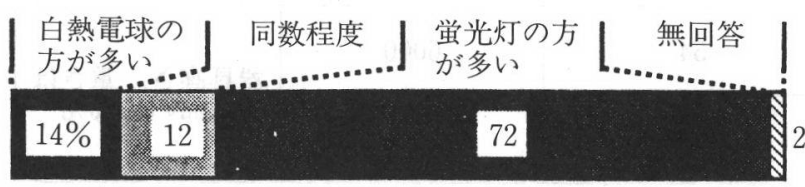

図 1 住宅照明の白熱灯と蛍光灯の割合

\section{3. 高周波点灯専用形環形蛍光ランプ用器具共 通事項}

高周波点灯専用形環形蛍光ランプには，T5 環形蛍光 ランプ2) と重環形蛍光ランプ4)5)の 2 タイプのランプが 存在するが, 器具の特徵はランプの特徵により似ている が, 使われ方により特徴が少し異なる. 異なる部分は, 後の項で説明するとして共通の特徵を先に説明する.

\section{1 省メンテ, 省資源}

$\mathrm{T} 5$ 環形蛍光ランプ, 二重環形蛍光ランプともランプ 定格寿命が従来ランプの6000時間に対して1.5倍の 9000 時間となる。それによりランプ交換回数低減による省メ ンテと資源の有効活用がはかれる。また，直付器具のカ バーは，帯電防止処理などによりホコリの付きにくいア クリルを使用し，掃除の手間を軽減している。

\section{2 高調波対応}

搭載する点灯装置は, 高周波点灯装置 (インバー夕) と なり, ちらつきなし, $50 / 60 \mathrm{~Hz}$ 兼用, 瞬時点灯, 軽量化 の他に電源電圧等の歪を抑制した高調波対策が施され， 電源供給元や他機器への影響の少ない「家電・沉用品高 調波抑制がイドライン」クラス C に適合したものとなっ ている.

\section{3 省施工}

直付器具では, 点灯装置, ランプ, プラスチック反射 板やアルミ製シャーシによる器具の軽量化等とあいまっ て, 天井の引掛シーリングに簡単取り付られる省施工の 器具となっている.

\section{T5 環形蛍光ランプ器具の特徵2)3}

$\mathrm{T} 5$ 環形蛍光ランプの概要は従来の $30 \mathrm{~W}$ 形, $32 \mathrm{~W}$ 形, 40W 形環形蛍光ランプの外径寸法を同じくしたまま, 管 径のみ $29 \mathrm{~mm}$ から $16.5 \mathrm{~mm}$ と細くしたことが外観上の 特徵であり, 従来の環形蛍光ランプ同様 G10q の口金を 具備している. 電気特性上はそれぞれに定格出力と高出 力を有し, 定格出力時は従来ランプと同じ明るさを $10 \%$ 少ない電力で点灯でき, 高出力時は, 従来ランプの1.3倍 の光出力になっている (図 2, 表 1).

$\mathrm{T} 5$ 環形蛍光ランプ搭載器具の特徵は, 各社より様々 な器具が出ているが, 各社とも「スリム」「明るい」「省 メンテ」をキーワードにしたものが多い. 


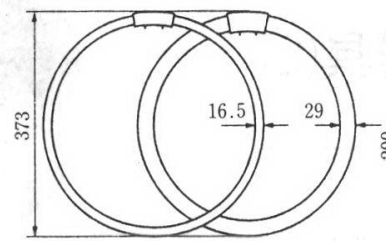

FHC34

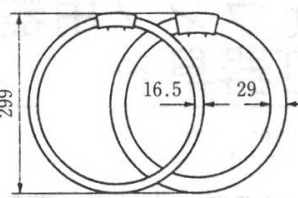

FHC27 FCL32

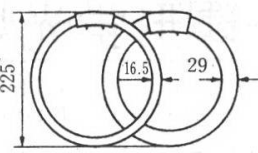

FHC20 FCL30

図 2 新旧ランプ寸法比較（単位： $\mathrm{mm}$ )

表 1 新旧ランプ電気特性比較

\begin{tabular}{|c|c|c|c|c|c|}
\hline & & $\begin{array}{c}\text { ランプ電力 } \\
(\mathrm{W})\end{array}$ & $\begin{array}{l}\text { 全光束 } \\
(\operatorname{lm})\end{array}$ & $\begin{array}{l}\text { 定格寿命 } \\
\text { (h) }\end{array}$ & $\begin{array}{l}\text { 消費効率 } \\
(\mathrm{lm} / \mathrm{W})\end{array}$ \\
\hline $\begin{array}{l}\text { 従来環形蛍光ランプ } \\
\text { FCL 40EX - N } / 38\end{array}$ & & 38 & 3270 & 6000 & 86.1 \\
\hline \multirow{2}{*}{$\begin{array}{l}\text { T5 環形蛍光ランプ } \\
\text { FHC34EN }\end{array}$} & 定格点灯 & 34 & 3270 & 9000 & 96.2 \\
\hline & 高出力 & 48 & 4250 & 9000 & 88.5 \\
\hline
\end{tabular}

注）消費効率は, ’ $99 / 3$ 時点の測定法による.

ランプ周囲温度 $25^{\circ} \mathrm{C}$

\section{1 「スリム」：薄形化，省梱包，省資源}

直付器具では, 薄型化を特徵としたものが多く。従来 器具の高さが, $160 \mathrm{~mm}$ であったものが, $100 \mathrm{~mm}$ と $40 \%$ の薄型化がはかれ，居住空間をより広々使えるとしてい る(図 3 ).

また,「スリム」化のメリットは, 梱包資材の削減（従 来比 $45 \%$ 削減）(図 4 ）にも一役かっており, ランプの ガラス量については，1本当たりの削減量の低減（従来 比 $45 \%$ ）と長寿命化（1.5倍）により従来比 $63 \%$ の削減 に值する (図 5).

\section{2 「明るい」}

従来の同様な大きさの器具と比較し約 $60 \%$ 明るさを アップしている(表2).

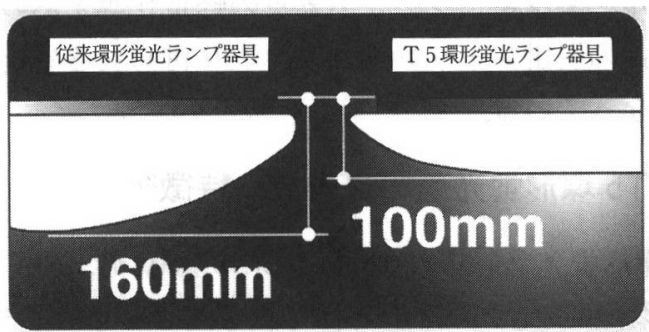

図 3 新旧直付器具の比較（器具高さ）

\section{3 「省メンテ」}

ランプの寿命が1.5に伸びたのに加え，細くなったラ ンプをより扱いやすくし, 誰でも安全確実にランプの着 脱ができるワンタッチホルダー付きの器具（図6）など がある。

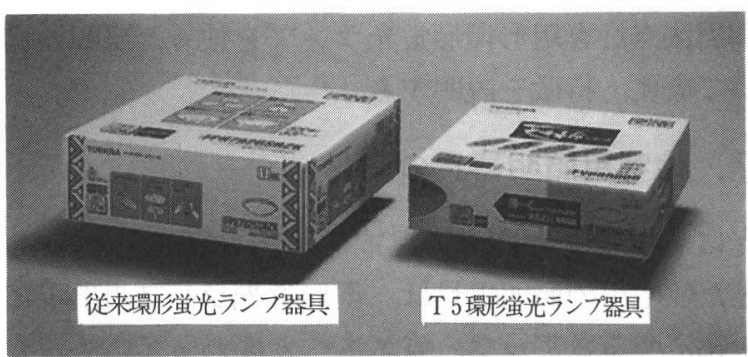

図 4 新旧器具棝包比較

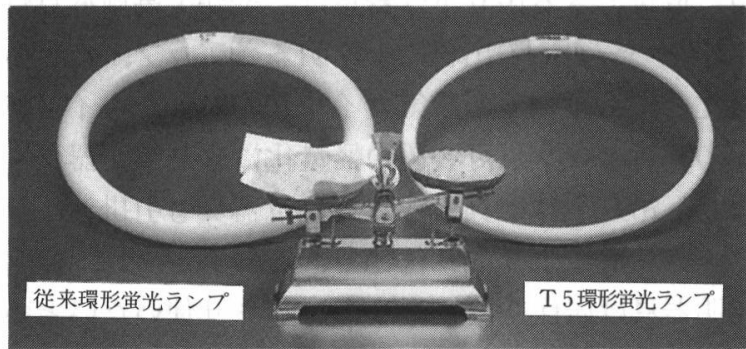

図 5 新旧ランプガラス量比較

表 2 新旧器具電気特性比較 ${ }^{3)}$

\begin{tabular}{|c|c|c|c|c|c|}
\hline & $\begin{array}{l}\text { 消費電力 } \\
(\mathrm{W})\end{array}$ & $\begin{array}{c}\text { ランプ全光束 } \\
(\mathrm{lm})\end{array}$ & $\begin{array}{c}\text { エネルギー消費効率 } \\
(\mathrm{lm} / \mathrm{W})\end{array}$ & $\begin{array}{c}\text { ランプの定格寿命 } \\
(\mathrm{h})\end{array}$ & 備考 \\
\hline $\begin{array}{l}\text { 従来環形巣光ランプ器具 } \\
(\mathrm{FCL} 40+32)\end{array}$ & 86 & 4640 & 54 & 6000 & \multirow{2}{*}{$\begin{array}{l}\text { 器具高さ, 重さは } \\
\text { 従来品の約 } 60 \%\end{array}$} \\
\hline $\begin{array}{l}\mathrm{T} 5 \text { 環形蛍光ランプ器具 } \\
\text { (FHC34 }\end{array}$ & 86 & 7500 & 87 & 9000 & \\
\hline
\end{tabular}

注）エネルギー消費効率は，' $99 / 3$ 時点の測定法による。 


\section{4 その他 (使い勝手, 光演出, 器具形態)}

その他には，リビング等の使用を考慮して引きUもが 収納でき，かつ，壁スイッチでも点灯順序の切り替えが できるものやリモコン付きのものが商品化されている. リモコン付きの器具の中には，1台の器具に光色の違う 2 種類のランプを組み込んでそれぞれのランプを全光, 調光，消灯と制御することで，従来白熱灯と蛍光灯の組 み合わせで行っていた光演出を省工ネかつ，簡単に実現 出来る器具もある。

現在, 消費電力の違う 2 灯， 3 灯の組み合わせの直付 器具や吊り下げ器具が主流であるが，1灯用の直付器具, 同じ消費電力のランプを 4 灯や 5 灯使った器具が商品化 されている。

\section{5. 二重環形蛍光ランプ器具の特徵34)5)}

二重環形ランプの概要は, 従来の $30 \mathrm{~W}$ 形, $32 \mathrm{~W}$ 形, 40 $\mathrm{W}$ 形に近い外径であるが, 管径 $20 \mathrm{~mm}$ のランプを二重に して先端をブリッジで繋いだ形になっており，従来の ワットの違う 2 本のランプを細くして1本にまとめたよ
うな形になっている、口金は, G10q となっているが, 片 口金のコンパクト蛍光ランプのようにガラス管と口金部 は完全に固定され，口金ピンが垂直に出ている（図 7, 表 3 ).

二重環形蛍光ランプ搭載器具の特徵としては,「明るい」 「高効率」「省メンテ」などをキーワードとしている。

\section{1 「明るい」「高効率（省エネルギー）」}

従来品と比較し同じ消費電力なら約 1.7 倍明るく，効 率は約1.8倍になる (表 4 )。

\section{2 その他 (使い勝手, 光演出, 器具形態)}

直付器具, 吊り下げ器具は，1本またはワットの違う 2 本の組み合わせ器具があり, 主流の直付器具では, 壁 スイッチでの点灯順序の切り替えを前提に，別売りのリ モコン送信機によりリモコン器具として対応できるよう な仕様になっているものや，明るさアップのメリットを 活かし, 従来の順送りで点灯順序を切り替えるリモコン から明るさアップがダイレクトで選択できるもの，二重 環形ランプと白熱灯の組み合わせで白熱灯の間接光によ

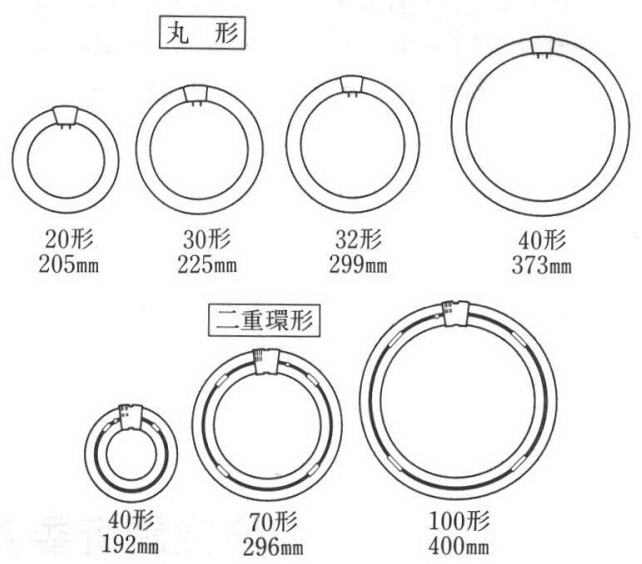

図 7 新旧ランプ寸法比較

図 6 ランプワンタッチホルダー器具

表 3 新旧ランプ電気特性比較

\begin{tabular}{|l|c|c|c|c|}
\hline & $\begin{array}{c}\text { ランプ電力 } \\
(\mathrm{W})\end{array}$ & $\begin{array}{c}\text { 全光束 } \\
(\mathrm{lm})\end{array}$ & $\begin{array}{c}\text { 定格寿命 } \\
(\mathrm{h})\end{array}$ & $\begin{array}{c}\text { 消費効率 } \\
(\mathrm{lm} / \mathrm{W})\end{array}$ \\
\hline $\begin{array}{l}\text { 従来環形蛍光ランプ } \\
\text { FCL40EXーN } / 38\end{array}$ & 38 & 2940 & 6000 & 77.4 \\
\hline $\begin{array}{l}\text { 二重環形蛍光ランプ } \\
\text { FHD100EN }\end{array}$ & 97 & $\begin{array}{c}8800 \\
(9600)\end{array}$ & 9000 & 99.0 \\
\hline
\end{tabular}

注）消費効率は，'99／3 時点の測定法による。

ランプ周囲温度 $25^{\circ} \mathrm{C} ， （ ）$ 内はランプ周囲温度 $40^{\circ} \mathrm{C}$

表 4 新旧器具電気特性比較

\begin{tabular}{|c|c|c|c|c|c|}
\hline & $\begin{array}{l}\text { 消費電力 } \\
(\mathrm{W})\end{array}$ & $\begin{array}{c}\text { ランプ全光束 } \\
(\mathrm{lm})\end{array}$ & $\begin{array}{c}\text { エネルギー消費効率 } \\
(\mathrm{lm} / \mathrm{W})\end{array}$ & $\begin{array}{c}\text { ランプの定格寿命 } \\
(\mathrm{h})\end{array}$ & 備考 \\
\hline $\begin{array}{l}\text { 従来環形鲎光ランプ器具 } \\
(\text { FCL230W×4) }\end{array}$ & 128 & 7560 & 59 & 6000 & \multirow{2}{*}{$\begin{array}{l}\text { 器具高さ, 重さは } \\
\text { 従茄の約 } 3 / 4\end{array}$} \\
\hline $\begin{array}{l}\text { 二重環形蛍光ランプ器具 } \\
\text { (FHD100W+40W) }\end{array}$ & 120 & 11900 & 99 & 9000 & \\
\hline
\end{tabular}

注）エネルギー消費効率は，' $99 ／ 3$ 時点の測定法による。 
り TV，ビデオ鑑賞に適した光演出をするものがある. その他には，最小径のランプの組み合わせによるシャ ンデリア, 直付器具とフロアスタンドや埋め込み形の器 具が商品化されている（図８）.

\section{6.おわりに}

現在照明器具をとりまく環境として，高齢化による明 るさアップ，省エネに対する新基準の設定（省エネ法の 改正1999.4.1.) や購入者への PR（グリーン購入ネッ トワークによる環境情報の提供）とまさに今回説明した

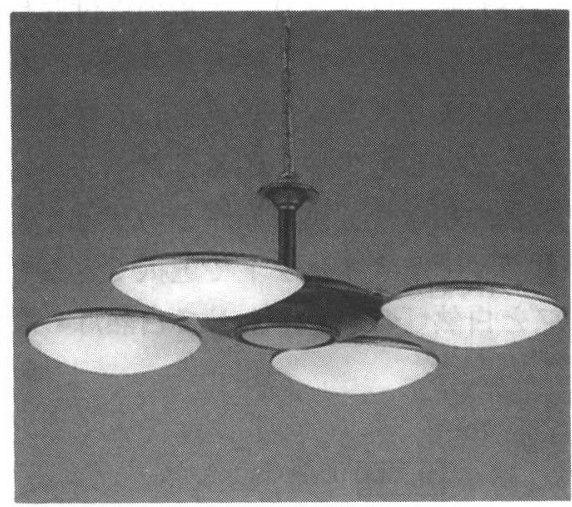

図 8 シャンデリアの例
高周波点灯専用蛍光ランプ及び器具が一つの回答，手段 である。それは，日本だけでなく欧米諸国でも同じであ $\eta$, 高周波点灯専用細形の蛍光ランプは, 従来の直管夕 イプだけでなく海外でも高周波点灯専用の T5 環形蛍光 ランプが発表され，T5 環形蛍光ランプ，二重環形蛍光ラ ンプ共に IECへの規格化が進んでいる. 今後, これらの ランプ及び器具により高齢者でも快適に生活できる「人 にやさしい」光環境の実現と省工ネ, 省資源による「地 球にやさしい」社会に貢献できるランプ及び器具システ ムが普及することを期待する。

\section{参考文献}

（1）佐藤：住宅照明の現状と将来, 照学誌, p.693（1996）

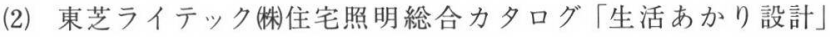
1999-2000

（3） (社)照明学会, 共生のあかり

(4) 松下電工(株)住宅・店舗照明力タログ’99

(5) 松下電器産業侏)ランフカタログ，99-4

\section{一研究調査委員会報告書頒布のお知らせ}

報告書名：CIE グレア評価法 UGR の研究調査報告書（JIER-060）

目次

1.はじめに

2. UGRについて

3. UGR と主観評価との対応

4. 代表的器具の計算例

5. 結論・課題
編集：平成11年 3 月

印刷：平成11年 4 月

発行：平成11年 5 月

頒布価格：会員 3000円 (税抜価格)

会員外3500円（税抜価格）

送料 1 冊 170 円

申込方法：必要事項(書籍名, 住所, 氏名, 電話, FAX, 会員は会員番号）をご記入の上，事務局へ お申込下さい.

FAX : 03-5294-0102 